\title{
ZBTB7A Gene
}

National Cancer Institute

\section{Source}

National Cancer Institute. ZBTB7A Gene. NCI Thesaurus. Code C43388.

This gene is involved in regulation of transcription and plays a role in cell organization/biogenesis. 